\title{
The use of dehulled or fat-supplemented yellow lupin seeds in feeding growing pigs
}

\author{
Marianna Flis', W. Sobotka' and Z. Meller ${ }^{2}$
}

\author{
'Institute of Animal Nutrition and Fe'ed Management \\ ${ }^{2}$ Department of Evaluation and Utilization of Animal Raw Materials. \\ Olsztyn University of Agriculture and Technology \\ Oczapowskiego 5, 10.718 Olsztyn, Poland
}

(Received 4 September 1995; accepted 12 January 1996)

\begin{abstract}
Two methods of increasing the energy content of yellow lupin seeds for growing pigs were studied: (1) dehulling of seeds and (2) the addition of fat to diets containing lupin. An additional aim of the study was to delermine the effectiveness of lysine and methionine supplementation of lupin-containing feeds. Experiment I, lasting 39 days, was carried out on 25 barrows with an average body weight of $27 \mathrm{~kg}$. Expcriment II was carricd out on 25 barrows weighing from 30 to $100 \mathrm{~kg}$. In both experiments, the animals were fed individually using isoprotein feed mixtures. Daily weight gain, feed utilization, nutrient digestibility, nitrogen balance and, in experiment II, carcass quality were determined.

Supplementing lupin-containing mixtures with lysine and methionine increased daily weight gain by $10 \%$ and nitrogen retention by $21 \%$ (Experiment I). The addition of fat to ccrcal-lupin diets led to $7.6 \%$ higher daily weight gains in Expteriment $\mathrm{I}(\mathrm{P}<0.05)$, and $14.2 \%$ higher gains in Experiment II $(\mathrm{P}<0.01)$ over the entire period of the experiment. The use of deulled lupin seeds increased weight gain by $4.8 \%(P>0.05)$ in Expt. I and by $13.5 \%(P<0.01)$ in Expt. Il. It was found that yellow lupin can completely replace soyabean oilmeal in the diets for pigs of over $30 \mathrm{~kg}$ body weight, under the condition that the diels are balanced in respect to lysine and methionine. The nutritive value of diets containing mostly barley and yellow lupin can be improved by adding fat or dehulling seeds.
\end{abstract}

KEY WORDS: yellow lupin, dchulling, fat, amino acids, pigs

\section{INTRODUCTION}

Lupin secds contain negligible amounts of starch, but large amounts of nonstarch polysaccharides (NSP) and $\alpha$-galactosides, which are digested in the small intestine of pigs to a very small extent but are fermented in large intestine 
(Taverner et al., 1983). This may lead to flatulence as well as to insufficient net energy uptake from lupin seeds, despite their high gross and digestible energy value. The data of Fernandez and Batterham (1992) show that the net energy of soyabean oilmeal is equal to $52 \%$ of its gross energy content, while that of narrow-leaved lupin only $43 \%$. The high digestibility of lupin nutrients in the entire digestive tract, which is the basis for calculating the energy value of feeds for pigs, may lead to overestimation of the energy value of lupin, especially for younger animals.

This problem is more pertinent in respect to yellow lupin, which in comparison with white or narrow-lcaved lupin seeds, contains more seed hull and $\alpha$-galactosides (Brillouet and Riochet, 1983; Trugo and Almeida, 1988; Saini, 1989). It seems, then, that dehulling seeds, and so elimination most of the NSP, may increase the energy value of these sceds for pigs.

The aim of this study was to compare the effectiveness of two methods of increasing the energy value of yellow lupin seeds for growing pigs: (1) dehulling seeds, (2) adding fat to a diet containing lupin. An additional objective of the study was to assess the effectiveness of supplementing lupin-containing diets with lysine and methionine.

\section{MATERIAL $\Lambda$ ND METHODS}

\section{Animals and diets}

Two experiments were carried out.

Experiment I was done on 25 barrows, crossbreds of the the Polish Large White and Polish Landrace, with initial weights of $27.3 \mathrm{~kg}$. The pigs were fed individually for a period of 39 days on the complete isoprotein feeds (Table 1). The soyabcan oilmcal that supplemented barley and wheat (group 1) was replaced by lupin (group 2), lupin supplemented with lysine and methionine according to the German standards (DLG, 1987) (group 3), lupin with added soyabean oil (group 4), dehulled lupin (group 5). The diets fed to groups 1,3,4 and 5 had similar lysine and methionine contents. The feeds were given in moist form ( $1: 1$ with water) in amounts increased from 1.4 to $2.3 \mathrm{~kg}$ per day, twice daily. Nutrient digestibility and nitrogen balance were determined in pigs with body weights averaging $48.8 \mathrm{~kg}$.

Experiment II was carried out on 25 crossbred barrows with an average initial weight of $29.8 \mathrm{~kg}$. During fattening to $100 \mathrm{~kg}$ body weight, the pigs were fed individually using isoprotein feed mixtures (Table 2), containing soyabean 
TABLE, 1

Composition and nutritional valuc of dicts (Experiment I)

\begin{tabular}{|c|c|c|c|c|c|}
\hline \multirow[b]{2}{*}{ Indices } & \multicolumn{5}{|c|}{ Groups } \\
\hline & $\begin{array}{c}1 \\
(\mathrm{SBM})^{1}\end{array}$ & $\begin{array}{c}2 \\
\text { (SBMF) }\end{array}$ & $\begin{array}{c}3 \\
(\mathrm{~L})\end{array}$ & $\begin{array}{c}4 \\
(\mathrm{DL})\end{array}$ & $\begin{array}{c}5 \\
(\mathrm{LF})\end{array}$ \\
\hline \multicolumn{6}{|l|}{ Ingredients, $\%$} \\
\hline Barley & 55.5 & 57.5 & 57.2 & 52.2 & 61.2 \\
\hline Wheat & 25.0 & 25.0 & 25.0 & 25.0 & 25.0 \\
\hline Soyabean meal & 16.0 & - & - & - & - \\
\hline Lupin, whole & - & 14.0 & 14.0 & 15.0 & - \\
\hline Lupin, dehulled & - & - & - & - & 10.0 \\
\hline Soyabean oil & - & - & - & 4.0 & - \\
\hline Minerals ${ }^{2}$ & 2.5 & 2.5 & 2.5 & 2.5 & 2.5 \\
\hline Premix & 1.0 & 1.0 & 1.0 & 1.0 & 1.0 \\
\hline $\mathrm{L}$-lysine IICL, $\mathrm{g} / \mathrm{kg}$ & - & - & 0.23 & 0.23 & 0.23 \\
\hline DL-methionine, $\mathrm{g} / \mathrm{kg}$ & - & - & 0.06 & 0.06 & 0.06 \\
\hline \multicolumn{6}{|l|}{ Chemical composition, $\%$} \\
\hline Dry matter & 88.78 & 88.75 & 88.87 & 89.55 & 89.01 \\
\hline Crude protcin & 15.65 & 15.57 & 15.74 & 15.73 & 16.00 \\
\hline Ether exiract ${ }^{3}$ & 2.72 & 3.10 & 3.11 & 6.84 & 3.08 \\
\hline Crude fibre & 4.85 & 5.64 & 5.62 & 5.71 & 4.43 \\
\hline \multicolumn{6}{|l|}{ Nutrient contents, $\%$} \\
\hline Digcstible crude protein & 12.30 & 12.18 & 12.50 & 12.36 & 12.64 \\
\hline Lysine $e^{4}$ & 0.70 & 0.60 & 0.77 & 0.77 & 0.77 \\
\hline Lysine:crude protein. $\%$ & 4.47 & 3.85 & 4.89 & 4.90 & 4.81 \\
\hline Methionine ${ }^{4}$ & 0.24 & 0.20 & 0.25 & 0.25 & 0.25 \\
\hline Methionine:lysine, $\%$ & 34.3 & 33.3 & 32.5 & 32.5 & 32.5 \\
\hline Met + cys $^{4}$ & 0.53 & 0.53 & 0.58 & 0.58 & 0.58 \\
\hline Mctabolizable cnergy, MJ $/ \mathrm{kg}$ & 12.61 & 12.44 & 12.50 & 13.40 & 12.78 \\
\hline
\end{tabular}

'SBM - soyabean meal, L - lupin, LA - lupin + amino acids, LAF - lupin + amino acids : lat, DLA - dehulled lupin - amino acids

${ }^{2}$ bicalcium phosphate $(1.3 \%)$, limestone $(0.9 \%)$, salt $(0.3 \%)$

${ }^{3}$ determined after HCL hydrolysis

${ }^{4}$ values calculated

oilmeal (group 1), soyabean oilmeal with added fat (group 2), lupin (group 3), dehulled lupin (group 4), lupin with added fat (group 5). The protein, amino acid and mineral content of the feeds was balanced according to the Nutrient Requirements of Pigs (1993). The feed mixtures were given in moist form (1:1 with water) twice daily. Nutrient digestibility and nitrogen balance were detcrmined in pigs with average body weights of $61.8 \mathrm{~kg}$.

Faeces and urine collections were carried out during 5-day periods. Two average samples of faeces, $10 \%$ of daily collection, were taken. One was 
TABLE 2

Composition and nutritional value of diets (Experiment II)

\begin{tabular}{|c|c|c|c|c|c|}
\hline \multirow[b]{2}{*}{ Indices } & \multicolumn{5}{|c|}{ Groups } \\
\hline & $\begin{array}{c}1 \\
(\mathrm{SBM})^{1}\end{array}$ & $\begin{array}{c}2 \\
\text { (SBMF) }\end{array}$ & $\begin{array}{c}3 \\
(\mathrm{~L})\end{array}$ & $\begin{array}{c}4 \\
\text { (DL) }\end{array}$ & $\begin{array}{c}5 \\
(\mathrm{~L} F)\end{array}$ \\
\hline \multicolumn{6}{|l|}{ Ingredients, $\%$} \\
\hline Barley & 52.9 & 48.9 & 51.7 & 57.2 & 47.7 \\
\hline Wheat & 25.0 & 25.0 & 25.0 & 25.0 & 25.0 \\
\hline Soyabean meal & 19.0 & 20.0 & - & - & - \\
\hline Lupin whole & - & - & 20.0 & - & 21.0 \\
\hline Lupin. dchulled & - & - & - & 14.5 & - \\
\hline Soyabean oil & - & 3.0 & - & - & 3.0 \\
\hline Mineral feeds ${ }^{2}$ & 2.0 & 2.0 & 2.0 & 2.0 & 2.0 \\
\hline Premix & 1.0 & 1.0 & 1.0 & 1.0 & 1.0 \\
\hline L-lysine HCL, g/kg & 0.91 & 0.77 & 2.20 & 2.50 & 2.13 \\
\hline DL-methionine, $\mathrm{g} / \mathrm{kg}$ & 0.07 & 0.08 & 0.58 & 0.56 & 0.47 \\
\hline \multicolumn{6}{|l|}{ Chemical composition, $\%$} \\
\hline Dry matter & 87.74 & 88.09 & 87.84 & 87.99 & 87.93 \\
\hline Crude protein & 16.35 & 16.34 & 16.12 & 16.41 & 16.20 \\
\hline Ether extract ${ }^{3}$ & 2.89 & 5.78 & 3.26 & 3.53 & 6.21 \\
\hline Crude fibre & 4.77 & 4.47 & 6.41 & 4.26 & 6.50 \\
\hline \multicolumn{6}{|l|}{ Nutrient contents, $\%$} \\
\hline Digestible crude protein & 12.52 & 12.99 & 12.12 & 12.88 & 12.81 \\
\hline Lysine & 0.84 & 0.84 & 0.84 & 0.84 & 0.84 \\
\hline Methionine ${ }^{4}$ & 0.25 & 0.25 & 0.25 & 0.25 & 0.25 \\
\hline $\mathrm{Met}+\mathrm{cys}^{4}$ & 0.54 & 0.52 & 0.54 & 0.52 & 0.55 \\
\hline Metabolizable energy, MJ $/ \mathrm{kg}$ & 12.17 & 12.91 & 11.97 & 12.45 & 12.67 \\
\hline
\end{tabular}

${ }^{\mathrm{I}} \mathrm{SBM}$ - soyabean mcal, SBMF - soyabcan meal + fat. L - lupin. DL - dehulled lupin. LF - lupin + fat

${ }^{2}$ bicalcium phosphate $(0.6 \%)$, limestone $(1.1 \%)$, salt $(0.3 \%)$

3 determined after IICL hydrolysis

${ }^{4}$ values calculated

preserved with sulphuric acid (for $\mathrm{N}$ determination), the other was dried to determine the other nutrients and energy. Urine was collected into containers with sulphuric acid added in amunts lowering urinary $\mathrm{pH}$ to about 2 .

At the end of the experiment, carcass quality was determined using as criteria backfat thickness, loin eye area, ham dissection and loin protein and fat content.

Lupin of the Juno variety was used in both experiments. The seeds were dehulled on a semitechnological scale using a method developed at the Institute of Agricultural and Machinery and Equipment, Olsztyn University of Agriculture and Technology. The cotyledon yield equaled $68 \%$ in experiment $\mathrm{I}$, and $63 \%$ in experiment II (Table 3). 
TABLE 3

Composition of feeds (\% DM)

\begin{tabular}{|c|c|c|c|c|c|c|}
\hline \multirow[b]{2}{*}{ Ingredients } & \multicolumn{3}{|c|}{ Experiment I } & \multicolumn{3}{|c|}{ Experiment II } \\
\hline & $\begin{array}{c}\text { soyabean } \\
\text { meal }\end{array}$ & $\begin{array}{l}\text { whole } \\
\text { lupin }\end{array}$ & $\begin{array}{l}\text { dehulled } \\
\text { lupin }\end{array}$ & $\begin{array}{c}\text { soyabean } \\
\text { meal }\end{array}$ & $\begin{array}{l}\text { whole } \\
\text { lupin }\end{array}$ & $\begin{array}{l}\text { dehulled } \\
\text { lupin }\end{array}$ \\
\hline Dry matter & 90.24 & 89.17 & 91.48 & 87.54 & 87.09 & 90.85 \\
\hline Crude ash & 8.65 & 4.13 & 4.66 & 7.07 & 4.99 & 6.08 \\
\hline Crude protein & 42.29 & 46.85 & 57.27 & 48.75 & 45.01 & 56.32 \\
\hline Ether extract ${ }^{\prime}$ & 3.72 & 6.44 & 7.59 & 2.59 & 6.77 & 8.24 \\
\hline Crude fibre & 6.11 & 14.26 & 3.44 & 8.04 & 17.68 & 3.07 \\
\hline $\mathrm{NDF}$ & 14.43 & 22.20 & 7.61 & 19.39 & 24.71 & 7.85 \\
\hline $\mathrm{ADF}$ & 8.65 & 18.32 & 5.04 & 10.81 & 20.89 & 4.48 \\
\hline Lignin & $\mathrm{nd}^{2}$ & nd & nd & tracc & 1.54 & 0.55 \\
\hline Soluble carbohydrates & nd & nd & nd & 12.26 & 18.16 & 20.70 \\
\hline Starch & nd & nd & nd & 0.21 & 0.42 & 0.45 \\
\hline Total alkaloids & - & $0.141^{3}$ & $0.161^{3}$ & - & $0.061^{3}$ & $0.066^{3}$ \\
\hline
\end{tabular}

${ }^{1}$ determined after $\mathrm{HCL}$ hydrolysis

${ }^{2}$ not determined

${ }^{3}$ see material and methods

\section{Chemical analysis}

The nutrient content in feeds and, faeces, and urinary $\mathrm{N}$ were determined using conventional methods. NDF, ADF and lignin (ADL) were determined according to Van Soest and Wine (1967) using a Fibertex apparatus. In protein feeds starch was assayed enzymatically (Keppler and Decker, 1970), while soluble sugars according to Jacórzyński (1986). In experiment I lupin alkaloids were determined according to Skolik and Wiewiórkowski (1959), while in experiment II, according to Wysocka et al. (1989). Gross energy in feeds and faeces was determined by combustion in an adiabatic bomb.

\section{Statistical analysis}

The results of the experiments were subjected to statistical analysis of variance and Duncan multiple range test.

\section{RESULTS}

Dehulling yellow lupin seeds resulted in significant changes in their chemical composition (Table 3). The nonstarch polysaccharide content in dehulled fraction decreased: raw fiber from 14.1 to $3.4 \%$ (Experiment I) and from 17.7 to 
TABLE 4

Growth performance, digestibility coefficients and $\mathrm{N}$ balance (Expcriment $\mathrm{I}$ )

\begin{tabular}{|c|c|c|c|c|c|c|}
\hline \multirow[b]{2}{*}{ Indices } & \multicolumn{5}{|c|}{ Groups } & \multirow{2}{*}{$\begin{array}{r}P \\
\text { level }\end{array}$} \\
\hline & $\begin{array}{c}1 \\
(\mathrm{SBM})^{\prime}\end{array}$ & $\begin{array}{c}2 \\
\text { (L) }\end{array}$ & $\begin{array}{c}3 \\
(\mathrm{LA})\end{array}$ & $\begin{array}{c}4 \\
(\mathrm{LAF})\end{array}$ & $\stackrel{5}{5}$ & \\
\hline \multicolumn{7}{|l|}{ Ingredients, \% } \\
\hline Initial $\mathrm{BW}^{2}, \mathrm{~kg}$ & 27.10 & 28.10 & 27.60 & 27.10 & 26.70 & \\
\hline Final BW, kg & 53.30 & 52.72 & 54.34 & 55.78 & 54.68 & \\
\hline BW gain, g/day & $671^{\mathrm{cR}}$ & $621^{\mathrm{k} K}$ & $684^{\mathrm{bCAB}}$ & $736^{\mathrm{aA}}$ & $717^{\mathrm{atAB}}$ & 0,000 \\
\hline Fced : BW gain, $\mathrm{kg} / \mathrm{kg}$ & $2.61^{1, B}$ & $2.84^{\mathrm{aA}}$ & $2.56^{\mathrm{bc} \cdot \mathrm{B}}$ & $2.33^{\mathrm{dC}}$ & $2.46^{\mathrm{cdBC}}$ & 0.000 \\
\hline $\mathrm{ME}^{3}$ : $\mathrm{BW}$ gain, $\mathrm{MJ} / \mathrm{kg}$ & $33.0^{\mathrm{bAB}}$ & $35.3^{\mathrm{aA}}$ & $32.0^{\mathrm{bB}}$ & $31.2^{\mathrm{bH}}$ & $31.4^{64}$ & 0.001 \\
\hline $\mathrm{DCP}^{4}: \mathrm{BW}$ gain, $\mathrm{g} / \mathrm{kg}$ & $322^{\mathrm{bAB}}$ & $346^{\text {IA }}$ & $321^{\mathrm{b.AB}}$ & $288^{\circ \mathrm{C}}$ & $310^{\mathrm{bBC}}$ & 0.000 \\
\hline \multicolumn{7}{|l|}{ Digestibility coefficients, $\%$} \\
\hline Crude protein & 78.6 & 78.2 & 79.4 & 78.6 & 79.0 & 0.933 \\
\hline Ether extract & $46.8^{\mathrm{B}}$ & $47.7^{\mathrm{B}}$ & $48.7^{13}$ & $72.9^{4}$ & $49.9^{\mathrm{B}}$ & 0.000 \\
\hline Crude fibre & 36.1 & 26.9 & 22.5 & 29.8 & 27.9 & 0.190 \\
\hline $\mathrm{N}$-frec cxtractives & 91.0 & 90.4 & 90.2 & 90.6 & 91.4 & 0.599 \\
\hline Organic matter & 84.1 & 82.2 & 82.1 & 82.7 & 84.2 & 0.170 \\
\hline Gross energy & 81.4 & 79.1 & 78.5 & 80.4 & 81.0 & 0.154 \\
\hline \multicolumn{7}{|l|}{$N$ balance } \\
\hline Intake, g/day & 51.1 & 50.1 & 51.0 & 50.6 & 52.3 & \\
\hline Retention, g/day & $20.7^{\mathrm{atAB}}$ & $18.7^{\mathrm{bB}}$ & $22.8^{\mathrm{aA}}$ & $22.2^{\mathrm{a} \wedge \mathrm{B}}$ & $22.2^{\mathrm{a} \wedge \mathrm{B}}$ & 0.027 \\
\hline $\mathrm{N}$ retention: $\mathrm{N}$ intake, $\%$ & 40.4 & 37.3 & 44.8 & 43.9 & 42.5 & 0.068 \\
\hline $\mathrm{N}$ retention: $\mathrm{N}$ digested, $\%$ & $51.5^{\mathrm{ab}}$ & $47.7^{\mathrm{b}}$ & $56.4^{a}$ & $55.7^{\mathrm{a}}$ & $53.7^{\mathrm{ab}}$ & 0.043 \\
\hline
\end{tabular}

see Table 1

2 body weight

${ }^{3}$ metabolizable energy

${ }^{4}$ digestible crude protein

a, b, c $-\mathrm{P}<0.05 ; \mathrm{A}, \mathrm{B}-\mathrm{P}<0.01$

$3.1 \%$ (Experiment II), NDF from 22.2 to $7.6 \%$ and from 24.7 to $7.9 \%$, respectively, while lignin from 1.5 to $0.6 \%$. Removal of the seed coat caused a rise in the crude protein content to $56-57 \%$ DM, i.e. to a lcvel surpassing the amount of this nutrient in soyabean oilmeal. Dehulled seeds contained somewhat more raw fat, soluble sugars and alkaloids than whole seeds. The seeds used in experiment I contained about twice the amount of alkaloids as those used in experiment II (Table 3). Despite these differences, the pigs were equally willing to eat both lupin-containing diets and were healthy. It seems that the differences in alkaloid content could have resulted from the use of two different analytical methods (see Material and Methods).

In experiment I, total replacement of soyabean oilmeal with lupin seeds without supplementing with lysine and methionine led to a highly significant, 
$7.5 \%$ decrease in daily weight gains, and nitrogen retention $(\mathbf{P}<0.05)$ as well as to significant decrease $(\mathrm{P}<0.01)$ of feed conversion rate (Table 4$)$. When lysine and methionine were added to the feed containing lupin, weight gains and feed utilization were slightly higher than in the control group. Of the two methods of increasing the energy content of lupin, the addition of fat was more effective ( $7.6 \%$ greater weight gains) than dehulling seeds ( $4.8 \%$ greater gains). Addition of fat significantly increased feed utilization $(P<0.01)$. Nutrient digestibility of the lupin-containing feeds was similar to their digestibility in feeds with soyabean oilmeal. Crude fat in the mixture containing added soyabean oil (group 4) was better digested $(\mathrm{P}<0.01)$ than in the mixture without added oil (Table 3).

In experiment II (Table 5), the pigs grew more slowly than in experiment I. In the feed mixtures that were balanced for crude protein, lysine and methionine,

TABLE 5

Body weight gain and feed efficiency (Experiment II)

\begin{tabular}{|c|c|c|c|c|c|c|}
\hline \multirow[b]{2}{*}{ Indices } & \multicolumn{5}{|c|}{ Groups } & \multirow{2}{*}{$\begin{array}{r}P \\
\text { level }\end{array}$} \\
\hline & $\begin{array}{c}1 \\
(\mathrm{SBM})^{\prime}\end{array}$ & $\begin{array}{c}2 \\
(\mathrm{SBMF})\end{array}$ & $\begin{array}{c}3 \\
\text { (L) }\end{array}$ & $\begin{array}{c}4 \\
(\mathrm{DL})\end{array}$ & $\begin{array}{c}5 \\
(\mathrm{LF})\end{array}$ & \\
\hline Initial $\mathrm{BW}^{2}, \mathrm{~kg}$ & 30.5 & 29.3 & 30.5 & 29.3 & 29.5 & \\
\hline Final $\mathrm{BW}, \mathrm{kg}$ & 98.9 & 100.1 & 98.7 & 101.1 & 100.2 & \\
\hline \multicolumn{7}{|l|}{ BW gain, g/day } \\
\hline $30-60$ & $493^{\mathrm{b} \cdot \mathrm{B}}$ & $542^{\mathrm{abAB}}$ & $471^{\mathrm{cB}}$ & $587^{\mathrm{aA}}$ & $587^{\mathrm{aA}}$ & 0.001 \\
\hline $60-100$ & $716^{\text {lXAB }}$ & $749^{\mathrm{bcAB}}$ & $701^{\mathrm{cB}}$ & $763^{\mathrm{aAB}}$ & $773^{\text {aA }}$ & 0.018 \\
\hline $30-100$ & $607^{\mathrm{b} C A \mathrm{~B}}$ & $645^{\mathrm{abAB}}$ & $591^{\mathrm{cB}}$ & $671^{\mathrm{a \Lambda}}$ & $675^{\mathrm{aA}}$ & 0.001 \\
\hline \multicolumn{7}{|c|}{ Feed : BW gain, $\mathrm{kg} / \mathrm{kg}$} \\
\hline $30-60$ & $3.91^{\mathrm{thAB}}$ & $3.58^{\mathrm{hcAR}}$ & $4.13^{\mathrm{aA}}$ & $3.31^{\mathrm{cB}}$ & $3.32^{\mathrm{cB}}$ & 0.003 \\
\hline $60-100$ & $4.11^{\mathrm{abAB}}$ & $3.92^{\mathrm{br} A \mathrm{~B}}$ & $4.20^{\mathrm{a} . \mathrm{A}}$ & $3.84^{\mathrm{b} \times \mathrm{AAB}}$ & $3.77^{\mathrm{cB}}$ & 0.010 \\
\hline $30-100$ & $4.02^{\mathrm{AB}}$ & $3.77^{\mathrm{BC}}$ & $4.17^{A}$ & $3.60^{\mathrm{C}}$ & $3.56^{\mathrm{C}}$ & 0.000 \\
\hline \multicolumn{7}{|c|}{$\mathrm{ME}^{3}: \mathrm{BW}$ gain, $\mathrm{MJ} / \mathrm{kg}$} \\
\hline $30-60$ & $47.6^{\mathrm{ab}}$ & $46.4^{\mathrm{abc}}$ & $49.4^{a}$ & $41.2^{\mathrm{c}}$ & $42.1^{\mathrm{cb}}$ & 0.024 \\
\hline $60-100$ & 50.0 & 50.7 & 50.4 & 47.8 & 47.8 & 0.175 \\
\hline $30-100$ & $48.9^{\mathrm{aAB}}$ & $48.8^{\mathrm{aAB}}$ & $49.9^{\mathrm{aA}}$ & $44.8^{\mathrm{bB}}$ & $45.1^{\mathrm{bR}}$ & 0.008 \\
\hline \multicolumn{7}{|c|}{$\mathrm{DCP}^{4}$ : BW gain, $\mathrm{g} / \mathrm{kg}$} \\
\hline $30-60$ & $490^{a}$ & $465^{\mathrm{ab}}$ & $500^{a}$ & $426^{\mathrm{b}}$ & $425^{\mathrm{b}}$ & 0.026 \\
\hline $60-100$ & 515 & 510 & 510 & 495 & 483 & 0.248 \\
\hline $30-100$ & $503^{\mathrm{a}}$ & $492^{\text {ab }}$ & $506^{\mathrm{a}}$ & $464^{\mathrm{hc}}$ & $457^{\mathrm{c}}$ & 0.015 \\
\hline
\end{tabular}

\footnotetext{
' see Table 2

${ }^{2}$ body weight

${ }^{3}$ metabolizable energy

${ }^{4}$ digestible crude protein

$\mathrm{a}, \mathrm{b}, \mathrm{c}-\mathrm{P}<0.05 ; \mathrm{A}, \mathrm{B}-\mathrm{P}<0.01$
} 
complete replacement of soyabean oilmeal with lupin seeds did not negatively affect daily gains, while dehulling had a positive effect. In comparison with the gains of pigs fed unprocessed lupin, those fed dehulled lupin grew $24.6 \%$ faster $(\mathrm{P}<0.01)$ during the period of fattening from 30 to $60 \mathrm{~kg}, 8.8 \%$ faster $(\mathrm{P}<0.05)$ from 60 to $100 \mathrm{~kg}$ and $13.5 \%$ faster $(\mathrm{P}<0.01)$ during the entire fattening period. The effectiveness of dehulling lupin seeds was comparable to adding fat to the cereal-lupin diet. Adding fat also led to greater body weigh gains: by 24.6 (30-60 $\mathrm{kg} \mathrm{BW}), 10.3(60-100 \mathrm{~kg} \mathrm{BW})$ and $14.2 \%(30-100 \mathrm{~kg} \mathrm{BW})$. The addition of fat to the cereal-soyabean diet (group 2) had a favourable effect on the growth of animals; throughout the entire period of the experiment, body weight gains were $6.2 \%$ higher $(\mathrm{P}>0.05)$. The use of dehulled lupin (group 4 ), as well as the addition of fat to the cereal-lupin diet (group 5) significantly reduced feed to gain ratio-by 13.6 and $14.6 \%$, respectively, during the entire period of fattening in comparison with whole lupin (group 3). The addition of fat to the cereal-soyabean diet insignificantly reduced feed to gain ratio (by $6.2 \%$ ).

No significant differences were found in nutrient digestibility coefficients among the diets under study, with the exception of crude fat (Table 6). Crude fat in rations containing added soya oil was significantly $(\mathrm{P}<0.01)$ better digested than in diets without added oil. Using dehulled lupin or adding fat the diets containing whole lupin or soyabean meal caused an insignificant rise in the digestibility of crude protein, organic matter and energy.

TABLF: 6

Digestibility coefficients of nutrients and $\mathrm{N}$ balance (Experiment II)

\begin{tabular}{|c|c|c|c|c|c|c|}
\hline \multirow[b]{2}{*}{ Indices } & \multicolumn{5}{|c|}{ Groups } & \multirow{2}{*}{$\begin{array}{r}P \\
\text { level }\end{array}$} \\
\hline & $\begin{array}{c}1 \\
(\mathrm{SBM})^{\prime}\end{array}$ & $\begin{array}{c}2 \\
\text { (SBMF) }\end{array}$ & $\begin{array}{c}3 \\
(\mathrm{~L})\end{array}$ & $\begin{array}{c}4 \\
\text { (DL) }\end{array}$ & $\begin{array}{c}5 \\
(\mathrm{LF})\end{array}$ & \\
\hline \multicolumn{7}{|l|}{ Digestibility coefficient, $\%$} \\
\hline Crude protcin & 76.6 & 79.5 & 75.2 & 78.5 & 79.1 & 0.204 \\
\hline Ether extract & $43.6^{\mathrm{B}}$ & $66.8^{A}$ & $41.9^{\mathrm{B}}$ & $47.5^{\mathrm{B}}$ & $62.7^{\mathrm{A}}$ & 0.000 \\
\hline Crude fibre & 23.7 & 25.2 & 25.0 & 25.7 & 31.1 & 0.387 \\
\hline $\mathrm{N}$-free extractives & 88.3 & 88.7 & 88.4 & 88.4 & 88.7 & 0.966 \\
\hline Organic matter & 80.7 & 81.9 & 79.1 & 81.6 & 80.4 & 0.067 \\
\hline Gross energy & 77.7 & 79.6 & 76.3 & 78.5 & 78.2 & 0.060 \\
\hline \multicolumn{7}{|l|}{$N$ balance } \\
\hline Intake, g/day & 67.6 & 68.2 & 67.4 & 68.0 & 67.6 & \\
\hline Retention, g/day & 22.4 & 25.0 & 23.2 & 25.6 & 24.0 & 0.554 \\
\hline $\mathrm{N}$ retention: $\mathrm{N}$ intake, $1 \%$ & 33.1 & 36.6 & 34.4 & 37.6 & 35.6 & 0.555 \\
\hline $\mathrm{N}$ retention: $\mathrm{N}$ digested, $\%$ & 43.2 & 46.2 & 45.7 & 48.0 & 44.9 & 0.776 \\
\hline
\end{tabular}

'see Table 2

A, B $-\mathrm{P}<0.01$ 
TABLE 7

Carcass quality (Experiment II)

\begin{tabular}{|c|c|c|c|c|c|c|}
\hline \multirow[b]{2}{*}{ Indices } & \multicolumn{5}{|c|}{ Groups } & \multirow{2}{*}{$\begin{array}{c}\mathbf{P} \\
\text { level }\end{array}$} \\
\hline & $\begin{array}{c}1 \\
(\mathrm{SBM})^{\prime}\end{array}$ & $\begin{array}{c}2 \\
\text { (SBMF) }\end{array}$ & $\begin{array}{c}3 \\
(\mathrm{~L})\end{array}$ & $\begin{array}{c}4 \\
\text { (DL) }\end{array}$ & $\begin{array}{c}5 \\
(\mathrm{LF})\end{array}$ & \\
\hline BW $^{2}$ before slaughter, $\mathrm{kg}$ & 98.9 & 100.1 & 98.7 & 101.1 & 100.2 & \\
\hline Dressing percentage, $\%$ & 79.3 & 79.9 & 79.5 & 80.2 & 80.4 & 0.510 \\
\hline Backfat thickness $^{3}, \mathrm{~cm}$ & 2.74 & 3.19 & 2.63 & 2.74 & 2.81 & 0.401 \\
\hline Loin cyc arca, $\mathrm{cm}^{2}$ & 35.8 & 37.1 & 35.6 & 37.1 & 37.8 & 0.399 \\
\hline Weight of ham, $\mathrm{kg}$ & 9.28 & 9.32 & 9.25 & 9.51 & 9.60 & 0.832 \\
\hline Meat in ham, \% & 68.1 & 67.0 & 68.7 & 70.1 & 70.0 & 0.731 \\
\hline $\mathrm{pH}_{1}$ & $6.32^{\mathrm{abAB}}$ & $6.40^{\mathrm{nhAB}}$ & $6.10^{\mathrm{hB}}$ & $6.64^{\mathrm{aA}}$ & $6.46^{\mathrm{AAB}}$ & 0.018 \\
\hline $\mathrm{pH}_{\mathrm{u}}$ & 5.38 & 5.36 & 5.34 & 5.36 & 5.38 & 0.872 \\
\hline \multicolumn{7}{|c|}{ Contents in longissimus dorsi musule } \\
\hline Dry matter, $\%$ & 25.12 & 25.08 & 24.83 & 25.48 & 24.94 & 0.203 \\
\hline Crude protein, \% & 22.94 & 22.32 & 22.22 & 22.48 & 22.63 & 0.706 \\
\hline Ether extract, \% & $0.94^{\mathrm{bB}}$ & $1.46^{\mathrm{a} \Lambda}$ & $0.94^{\mathrm{bB}}$ & $1.52^{\mathrm{aA}}$ & $1.12^{\mathrm{b} \wedge \mathrm{B}}$ & 0.001 \\
\hline
\end{tabular}

' see Table 2

${ }^{2}$ body weight

${ }^{3}$ mean of three measurements

${ }^{4}$ without shank

a, $\mathrm{b}-\mathrm{P}<0.05 ; \mathrm{A}, \mathrm{B}-\mathrm{P}<0.01$

Daily nitrogen retention, determined at a body weight of about 62 kilograms, equaled 22.4 to $25.6 \mathrm{~g}$, and did not differ significantly among groups. However, $\mathrm{N}$ retention and utilization of digested nitrogen were somewhat higher $(\mathrm{P}>0.05)$ in pigs fed the cereal-soyabean ration plus oil (group 2) and in pigs fed the diet containing dehulled lupin (group 4) than in pigs from the other groups.

On the basis of the taken measurements, no differences in carcass quality were found (Table 7). Backfat thickness, loin eye area, ham weight and meat content, loin protein and fat content in pigs fed the cereal-soyabean diet were almost the same as in the pigs fed the cereal-lupin diet. The 3\% addition of fat to the cercal-soyabean diet (group 2) insignificantly increased the backfat thickness $(0.45 \mathrm{~cm})$, increased the loin eye area and significantly $(\mathrm{P}<0.01)$ increased loin fat content. Adding fat to the cereal-lupin diet had a similar effect on carcass quality as using dehulled lupin in the diet. In comparison with the pigs in group 3, fed unprocessed lupin, the carcasses of, pigs in group 5 had slightly thicker backfat, greater loin eye area and ham weight. The loin fat content was more affected by feeding dehulled lupin (a $61 \%$ nicrease) than by adding fat to the lupin diet (a 19\% rise). 


\section{DISCUSSION}

The increase in crude protein content in dehulled yellow lupin seeds (by $22 \%$ in experiment I and $25 \%$ in experiment II) is comparable to data obtained by Kwiatkowski and Golec (1987) and Vasquez et al. (1989). Dehulling the seeds eliminated $79 \%$ raw fibre, $75 \%$ ADF and $67 \% \mathrm{NDF}$. In the studies by Brenes et al. (1993), dehulled sweet lupin seeds contained $72 \%$ ADF and $73 \%$ NDF less than whole sceds. The chemical composition of dehulled seeds shows that the dehulling technique was effective and gave a product close to that obtained by manual remoral of hulls (Zduńczyk et al., 1994).

A significant positive effect of supplementing the barley-wheat-lupin diet with lysine and methionine on body weight gain, feed utilization and nitrogen balance in young growing pigs (Experiment I), confirms the deficit of these amino acids in this type of diet. It results from of the low lysine content of cereals and rather low lysine content and availability in lupin (Batterham, 1992), as well as the low content and digestibility of lupin seed methionine throughout the digestive tract of pigs (Wunsche et al., 1990; Wasilewko et al., 1994). The supplementing cereal-lupin diets with lysine and methionine, is therefore effective which is also confirmed by the results of other studies (Leibhol7, 1984; Fernandez and Batterham, 1992; Flis, 1993; Chachułowa et al., 1994; Gdala et al., 1994).

The addition of fat to the cereal-lupin diets affected favourably body weight gain and feed utilization, more in Experiment II in which smaller lupin seeds having more raw fibre were used. The same amount of fat added to the cereal-soyabean diet (Experiment II) only insignificantly increased gains. This means that in a diet with a high yellow lupin content, balanced in terms of the amount and quality of protein, energy was the factor limiting protein synthesis and growth of pigs, more than in the cereal-soyabean diet. The positive effect of increasing the energy level in the diets of pigs on protein synthesis and weight gains has been found in numerous studies (Grela and Jakobsen, 1991; Edwards and Campbell, 1992; De Greef et al., 1994).

Dehulling lupin seeds had a positive effect on their nutritional value. In experiment II, the effect of dehulling was comparable to the addition of $3 \%$ soyabean oil to the ration. It seems that removing the seed hulls, leading to a reduction in NDF, among others, contributes to the more intensive digestion of nutrients in the small intestine. This relationship in the case of narrow-leaved lupin was found by Fernandez and Batterham (1992).

A statistically highly significant increase in crude fat digestibility in diets containing added soyabean oil can in part be explained by the fact that the added oil is characterized by higher digestibility than the crude fat that is present in the component of the dietss, as well as by its higher content in these diets. 
In summarizing the results of this study, it can be stated that soyabean oilmeal can be completely replaced by yellow lupin in diets balanced in terms of lysine and methionine used in the feeding of pigs weighing over $30 \mathrm{~kg}$. The nutritional value of diets containing yellow lupin and barley can be increased by adding fat or dehulling seeds.

\section{REFERENCES}

Batterham E. S., 1992. Availability and utilization of amino acids for growing pigs. Nutr. Res. Rev. 5, $1-18$

Brencs A., Marquardt R. R., Guenter W., Rotter B. A., 1993. Effect of enzyme supplementation on the nutritional value of raw, autoclaved, and dehulled lupins (Lupinus albus) in chicken diets. Poultry Sci. 72, 2281-2293

Brillouet J.-M., Riochet D., 1983. Cell wall polysaccharides and lignin in cotyledons and hulls of seeds from various lupin (I upinus L.) species. J. Sci. Food Agic. 34, 861-868

Chachułowa J., Sokól L., Sawos7 E., Skomiał J., 1994. Supplementation of growing-Jinishing pigs feed mixtures containing ground lupin seeds with L-lysine and DL-methionine (in Polish). In: Polish Lupin Assotiation (Editor). Lupin-Protcin-Ecology, Poznań. pp. 141-143

Edwards A. C., Campbell R. G., 1991. Energy-protein interactions in pigs. In: W. Haresign, D. J. A. Cole (Editiors). Recent advances in animal nutrition Butterworth., pp. 3-19

Energic und Nährstoffbedarf landwirtschafticher Nutztierc. Nr. 4. Schweine. 1987. DLG Verlag. Frankfurt (Main)

Fernandez J. A., Batterham E. S., 1992. Lupin secd meal for pigs - how good are they? Proceedings of 4 th Biennial Pig Industry. Wollongbar, pp. 59-64

Flis M., 1993. Nutritive value of seeds of new varieties of field bean and yellow lupin for fattenning pigs (in Polish). Acta Acad. Agric. Tech. Olst., Zoot., 38, Suppl. A, pp. 3- 47

Gdala .J., Buraczewska L., Wasilewko J., 1994. Iteal digestibility of amino acids and nutritive value of protein of yellow lupin (Lupinus luteus) seeds for growing pigs (inPolish). In: The Kiclanowski Institute of Animal Physiology and Nutrition, Jablonna (Editor). Recent advances in swine nutrition, pp. $77-81$

Gdala J., Buraczewska L., Wasilewko J., 1995. Ileal digestibility of lupin seeds carbohydrates in young pigs and the effect of $\alpha$-galactosidase supplementation. Proceedings of 2 nd European Conference on Grain Legumes, Copenhagen-Denmark, p. 289

Greef K. H. de, Verstegen M. W. A., Kemp B., Van der Togt P. L., 1994. The effect of body weight and energy intake on the composition of deposited tissuc in pigs. Anim. Prod. 58. 263-270

Grela E., Jakobsen K., 1991. The effect of soybean oil and witamin E on performance and chemical composition of depot fat in growing pigs (in Polish). Ann. UMCS. Sect. EF., IX, 36, 291-296

Jacórzyński B., 1986. Oligosaccharides as a factor limiting feeding value of leguminous seeds (in Polish). Institute of Food and Feeding. Warszawa (Editor). Publ. No. 43 Keppler D., Decker K., 1970. Glykogen. Bestimmung mit Amyloglucosidasc. In: H. U. Bergmeyer (Editor). Methoden der enzymatischen Analyse. Band II Akademic Verlag. Berlin, pp. 1089-1094

Kwiatkowski M., Golec S., 1987. Possibilities of improvement feeding value of leguminous seeds (in Polish). Biul. inf. Przem. Pasz. 4, 40-46 
Leibholz J., 1984. A note on methionine supplementation of pig grower diets containing lupin-seeds meal. Anim. Prod. 38, 515-517

Nutrient Requirements of Pigs. Nutritive Value of Feeds (in Polish). 1993. The Kielanowski Institute of Animal Physiology and Nutrition, Jablonna (Editor)

Saini H. S., 1989. Legume seed oligosaccharides. In : J. Huisman, T. F. B. van der Poel, J. E. Liener (Editors). Recent advances of rewarch in antinutritional factors in legume seeds. Wageningen, pp. 329-341

Skolik J., Wicwiórowski M., 1959. Photometric micromethod for estimation of lupin alkaloids (in Polish). Roc7. Chemii, 33, 461-466

Soest P. J. van, Wine R. H., 1967. Lse of detergents in the analysis of fibrous feeds. IV. Determination of plant cell-wall constitucnts. J. Assoc. Off. Anal. Chem. 50, 50-55

Taverner M. R.. Curic D. M., Rayner C. M., 1983. A composition of the extent and site of encrgy and protein digestion of wheat, lupin and meat and bone meal by pigs. J. Sci. Food Agric. 34, $122-128$

Trugo L. C., Almeida D. C. F., 1988. Oligosaccharide contents in the secds of cultivated lupins. J. Sci. Food Agric. 45, 21-24

Wasilewko J., Buraczewska L., Gdala J., Grala W., 1994. Ileal digestibility of protein and amino acids of two lupin species in growing pigs (in Polish). In : Polish Lupin Assotiation (Editor). Lupin-Protein-Ecology. Poznań, pp. 135-140

Wünshe J., Henning U., Souffrant W.-B., Kreienbring F., 1990. Untersuchungen zur präzäkalen Rohproteinverdaulichkeit und Aminosäurenresorption von Lupinen beim Schwein. Arch. Anim. Nutr. 40, 831-839

Vasquez M., Knapp F., Guzman F., Zacarias I. 1989. Proteinas de lupino dulce (I.upinus luteus, var. Aurea / Wcico, y Lupinus alhus, var. Multolupa). 1. Extraccion y filtration por sephadex. Arch. Latinoamcr. Nutr. 39. 150-158

Wysocka W., Brukwicki T. Jaoszyski R., Hoffman K., 1989. A new and efficient method of extraction of alkaloids from lupin seeds. Lupin Newsletter, 13, 59-65

Zduńczyk Z., Juśkicwicz J., Frejnagel S., Flis M., Godycka I.. 1994. Chemical composition of the cotyledons and seed coat and nutritional value of whole and hulled seeds of yellow lupin. J. Anim. Feed Sci. 3, 141-148

\section{STRESZCZENIE}

Zastosowanic obłuskanych lub uzupelnionych tluszczem nasion łubinu żóltego $w$ żywieniu rosnących świń

Badano skuteczność zwiçkşenia wartości energetycznej dawek z nasionami łubinu żółtego dla rosnących świń: (1) poprzez. 7astosowanie w mieszance nasion obłuskanych lub (2) dodatek thuszczu do micszanki z łubincm. Ponadto określono skuteczność uzupełnienia lizyną i metioniną mieszanki z łubinem. Doświadezenic I, trwające 39 dni, wykonano na 25 wieprzkach o średniej masie ciala $27 \mathrm{~kg}$. doświadczenie II - na 25 wieprzkach od 30 do $100 \mathrm{~kg}$ masy ciała. W obydwóch doświadczeniach świnic żywiono indywidualnic izobiałkowymi mieszankami. Określano przyrosty dobowc, wykorzystanie paszy, strawność składników pokarmowych dawek, bilans azotu, a w doświadczeniu II tak $\%$ jakosic poubojową tus\%. 
Uzupełnienie lizyną i metioniną mieszanki z łubinem spowodowało większe, o $10 \%$, przyrosty dobowe i większą, o $21 \%$, retencję azotu (doświadczenie I). Dodatek thuszczu do diet zbożowo-łubinowych wpynął na zwiększenie przyrostów dobowych: w doświadczeniu I o 7,6 (P <0,05), w doświadczeniu II o 14,2\% $(\mathrm{P}<0,01)$ - średnio w całym okresie tuc $\%$. Skarmianie obłuskanych nasion łubinu spowodowało zwięk szenie przyrostów o 4,8 $(\mathbf{P}<0,05)$ - w doświadczeniu I, jo 13,5\% $(\mathbf{P}<0,01)$ - w doświadczeniu 1I. Stwierdzono, że łubinem żóltym można całkowicie zastạpić poekstrakcyjną śrutę sojową $w$ zbilansowanych, pod względcm zawartości lizyny i metioniny, mieszankach przeznaczonych dla świń powyżej $30 \mathrm{~kg}$. Wartość pokarmową dawek zawierających lubin zółty z przewaga jęczmienia można zwiękssyć poprzez dodatek do nich tłuszczu lub zastosowanie obłuskanych nasion. 